\title{
Natural Regeneration Population of Batang Rattan (Calamus zollingeri Beccari) in Nupabomba Village, Production Forest Area, Central Sulawesi
}

\author{
Titi Kalima, Diana Prameswari
}

Forest Research and Development Centre

Jl.Gunung Batu No.5 PO Box 165,Bogor, Indonesia 16680

Received September 5, 2018/Accepted December 26, 2018

\begin{abstract}
Thisresearchaimedto obtain information on the abundance and natural regeneration population of Calamus zollingeriBeccariand identify dominant trees in the site. The study used the descriptive method with a survey technique.A transect of $520 \mathrm{~m}$ consisting of 13 plots of $20 \times 20 \mathrm{~m}$ was established.The number of individuals, the lengths, and diameters of the stems for the seedlings, young, semi-mature, and mature cutting rattan were recorded along with the surrounding vegetation. Relative density, the frequency of rattan plants and treeswere summed to obtain the important value index (IVI) of each growth rate. The results showed that the natural regeneration population was quite abundant, i.e. 738.46, 296.15, 132.69, and 25.00 stems ha for seedlings, young, semi-mature, and mature rattan, respectively as a response to logging in which a number of the seedlings tended to increase after logging. The trees associated with C. zollingeri were Baccaurea rasemosa, Celtis philippensis, and Fagraea fragrans. The existence of seedling regeneration is a guarantee to the sustainability of C. zollingeri in the future. Therefore, forests with rattan need to be developed to improve the preservation, utilization, and conservation of its genetic resources, as well as enhancing the community awareness.
\end{abstract}

Keywords: superior local rattan, Calamus zollingeri, exploration, natural regeneration

*Correspondence author,email:diana_eko@yahoo.com, ;tel.+62-251-8633234; fax 0251-863111

\section{Introduction}

Calamus zollingeri Beccari is one of important superior local rattan species in Sulawesi out of 37 Calamus species (Kalima \& Jasni 2015). In Central Sulawesi forest area, this rattan was known as "rotan batang (batang rattan)" or angah (Rustiami 2011).

For the past three decades, Sulawesi has been a major source of large diameter canes used in the furniture industry, thus cane collecting is widespread. Rattan collection is common in Nupabomba such as in Lore Lindu National Park, where approximately $18-50 \%$ of the area is thought to be subject to intensive commercial cane harvesting (Siebert 2004).

The rattan flora of Central Sulawesi is abundant, speciesrich, and patchily distributed in lowland and montane forests (Siebert 2005). They can be found in the tropical regions of Asia, Africa, and Australasia (Shaanker et al. 2004). This makes Indonesia the number one country in the worldto harvest and export rattan (FAO 2011). Rattans can be found in small diameters $(<18 \mathrm{~mm})$ and large diametercanes $(>18$ $\mathrm{mm}$ ) (BSN 2017). Locals use both as livelihood commodities, but this study focuses mainly on large diameter species C. zollingeri because it is one of the commercially most important species (Siebert 2004). According to Siebert (2005), C. zollingeri are the main large diameter canes harvested by the villagers in villages within and around Nupabomba in Central Sulawesi, Indonesia. Rattan is used for many things. It is widely used for making furniture, household items, baskets, and even bridges (Siebert 2004).

Nupabomba, located in Central Sulawesi, is one of the lowland forests has been logged and cleared extensively for the establishment of plantation agriculture (Curran et al. 2004). Many upland areas have been set aside for protected areas (Groombridge \& Jenkins 2002). Nupabomba production forest area was one of the commercial rattan habitats $(C$. zollingeri). Themajority $(95 \%)$ of rattan harvested from wild populations used as a commercial commodity on a globalscale for the furniture industry is $C$. zollingeri (Jasni et al. 2012), which is also for foodstuffs ("sweet young cane/umbut manis") (Kidyoo \& McKey 2012). In Nupabomba, C. zollingeri grows among timber trees such as noi (Canariumasperum Benth.), marambaulu (Celtis philippensis Blanco), anloli (Fagraea fragrans Roxb.), soi (Dillenia serrata Thunb.), bayur (Pterospermum celebicum Miq.), ipi (Cryptocarya crassinerviopsis Kosterm.), renggo (Tarrietia utilis Sprague), and maraula 
(Diospyros macrophylla Blume). The diversity of supporting trees for rattan strongly affects the growth and the number of trunks per clump, andquality of the trunks (Arifin 2008).

Recently, the area is severely damaged by forest exploitation, and rattan has become threatened with overexploitation through unsustainable harvesting methods during past decades (Sunderland \& Dransfield 2002). As a result of very high harvesting pressures in the past, these specific canes are very rare, even in some certain locations they did not exist at all (Siebert 2005). However, when a cane is cut in, a clump vegetative buds grow. Therefore, information on natural regeneration population of $C$. zollingeri rattan needs to be studied. C. zollingeri rattan cane was harvested for the international furniture industry in Nupabomba region.

Starting from this fact where C. zollingeri is one of 37 all local superiority rattans, it is technically necessary to do research aimed at collecting data and information on natural regeneration and the abundance of $C$. zollingeri rattan in Nupabomba area, Central Sulawesi.

\section{Methods}

Study site This research was conducted in October 2015 in production forest of Nupabomba Village, Tanantovea Subdistrict, Donggala District, belong to forest area sof Production Forest Management Unit (KPHP) Dolago Tanggunung, Central Sulawesi (Figure 1). Geographically it was located at $0^{\circ} 35^{\prime} 32^{\prime \prime}-0^{\circ} 50^{\prime} 46^{\prime \prime} \mathrm{S}$ and $119^{\circ} 49^{\prime} 53^{\prime \prime}-120^{\circ}$ 02'40" East: thenorth borderson District of Labuan, the east on Moutong Parigi District, the south borderson City of Palu, the west borders with Gulf of Palu. Based on decree letter of Ministry of Forestry Numbered 635/Kpt-II/2013), KPHP region had an area of 16,924 ha (KPHP Model Dolago Tanggunung 2013).

Topography of KPHP Model Dolago Tanggunung were dominated by mountainous and hilly areas. The condition of the research sitewas a steep slope with a grade of $25-45 \%$. Altitude of location was 800-1900 m above sea level. Soil type was red-yellow podzolic soil (99.04\%), alluvial $(0.60 \%)$, and latosol $(0.36 \%)$. Dominant rainfall ranged $1,600-1,800 \mathrm{~mm}^{-1}$ year ${ }^{-1}$. The climate in this region is A type with a value of $\mathrm{Q}=0 \%$. Air temperature ranged between $25.70-27.10^{\circ} \mathrm{C}$, with an average maximum temperature of $26.56^{\circ} \mathrm{C}$. Air humidity ranged between $77-83 \%$, with an average of $79 \%$ (KPHP Model Dolago Tanggunung 2013).

The economic of Nupabomba Village communities are based on rattan collecting and agriculture of coffee and cacao. Agricultural activities arein protected forest areas of Nupabomba at slopes and higher elevation (compared to the valley in the village) and distance to the village is approximately $1 \mathrm{~km}$. Senoaji (2010) stated that some parts of protected forest areas of Nupabomba Village had undergone conversion to agricultural land and plantations (coffee) by communities which were called protected forest acoffee plantations area.

Field sampling and data collectionThe research presented based on the data collected from the sampleplots. The data

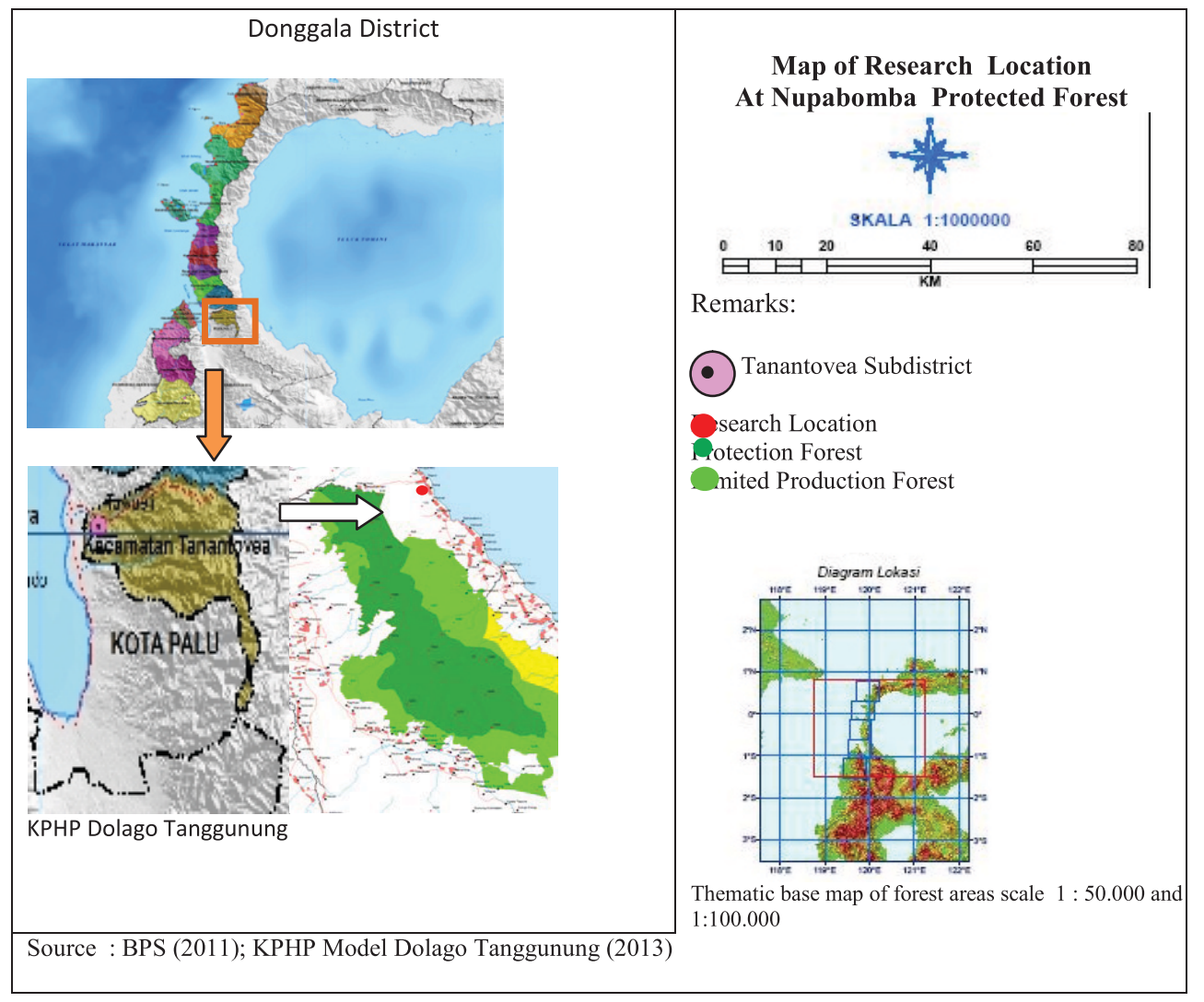

Figure 1 Map of research location at Nupabomba Village, Tanantovea Subdistrict, Donggala District, Central Sulawesi Province. 
used here relates to tree and composition.

Determining of sample plots The method used in this research was a descriptive method with techniques survey to obtain data on populations of $C$. zollingeri in Nupabomba forest areas. The rattan inventory used the same plots as for the tree measurements. After found the population, samples were taken using stripe plots (Soerianegara \& Indrawan 2005). The determination of plot observations done purposively with $10 \%$ intensity of an area of 16.924 ha. Implementation was started by determining the starting point, and then determined baseline which crossing the forests. Observations stripes were made perpendicular to the baseline. Sample plots were in the form of stripes (as long as $520 \mathrm{~m}$ ) with measuring plots of were $20 \times 20 \mathrm{~m}$ (square form), so that total measuring plots were 13 . The survey was conducted along with determined observations plots to find C. zollingeri Beccari species along with surrounding vegetation that associated with the rattan species within $10 \mathrm{~m}$ radius. The design and layout of the sample plots are illustrated in Figure 2.

Enumeration of rattan species The amount of individual species of $C$. zollingeri surrounding tree vegetation were counted. Enumeration of $C$. zollingeri rattan cane was carried out using grouping categories (Kalima 2004) as follows:

1 seedling stage, namely rattanhaving the length of stem $<3 \mathrm{~m}$,

2 young rattan (sapling), namely rattan with free leaf sheath length of $3-5 \mathrm{~m}$,

3 semi-mature rattan (pole), i.e., rattan with free leaf sheath, the length between $5-15 \mathrm{~m}$,

4 mature rattan (ripe harvest), namely rattan with free leafs heathlength $>15 \mathrm{~m}$.

Rattan abundance refers to the number of plants on each number of clumps for clustering rattan recorded in each quadrat. It is difficult to differentiate individual plants from the vegetative regeneration in a clump. One way of determining a distinct individual plant can be done by observing the cane length, previous harvest, and the number of canes (Siebert 2005).

Direct measurement of cane length is tough to be conducted in the field. Therefore, cane length estimation was carried out by the local guides who had been active as rattan collectors and are conversant with estimating the length of climbing canes.
Beside measurement of rattan stem length class, measurement was also conducted to rattan stem diameter class (BSN 2017) as follows:

1 diameter of 5-18 $\mathrm{mm}$ (small diameter),

2 diameter 19 to $34.9 \mathrm{~mm}$ (medium diameter),

3 diameter of $35-49 \mathrm{~mm}$ (large diameter),

4 diameter $>50 \mathrm{~mm}$ (super).

While for the accuracy of plants species scientific names, a collection of herbarium in the field was carried out.

\section{Analyses:}

Species identification If there were plants with unknown botanical names, then herbarium was made and later was identified at Herbarium Laboratory of Botany and Ecology, Forest Research and Development Centerin Bogor. Morphological characteristics and properties of species were known based on local name to get ascertain valid scientific name. Identification used several means namely comparing with herbarium specimens that having legitimate scientific names, using identification key by matching the description and herbarium specimens.

\section{Analyses:}

Estimation of rattan abundance species All obtained data were tabulated and analyzed to describe the abundance of rattan C. zollingeri Beccari by using observed variables: density $(\mathrm{K})$, relative density $(\mathrm{KR})$, frequency $(\mathrm{F})$, relative frequency (FR), dominance (D), relative dominance (DR), important value, and their population structures. All collected data were analyzed to obtain values according to the classification of Soerianegara and Indrawan (2005) as follows:

1 density, namely amount of individuals per plot $\left(520 \mathrm{~m}^{2}\right)$

2 frequency, namely amount of sample units $(20 \times 20 \mathrm{~m})$ in which the species were found.

3 basal area $\left(\mathrm{m}^{2}\right)=\pi \mathrm{d}^{2} 1 / 4$ Where: $\pi=$ phi or 3.14 , and $d=$ diameter of the stem

4 determination of Importance Value Index for poles and trees using equation IVI $(\%)=\mathrm{KR}+\mathrm{DR}+\mathrm{FR}$.

For seedling and saplings, determination of Important Value Index used the formula (IVI): IVI $(\%)=\mathrm{KR}+\mathrm{FR}$.

\section{Results and Discusion}

Population Status of $C$. zollingeri Beccari

Calamus zollingeri characteristics Based on research

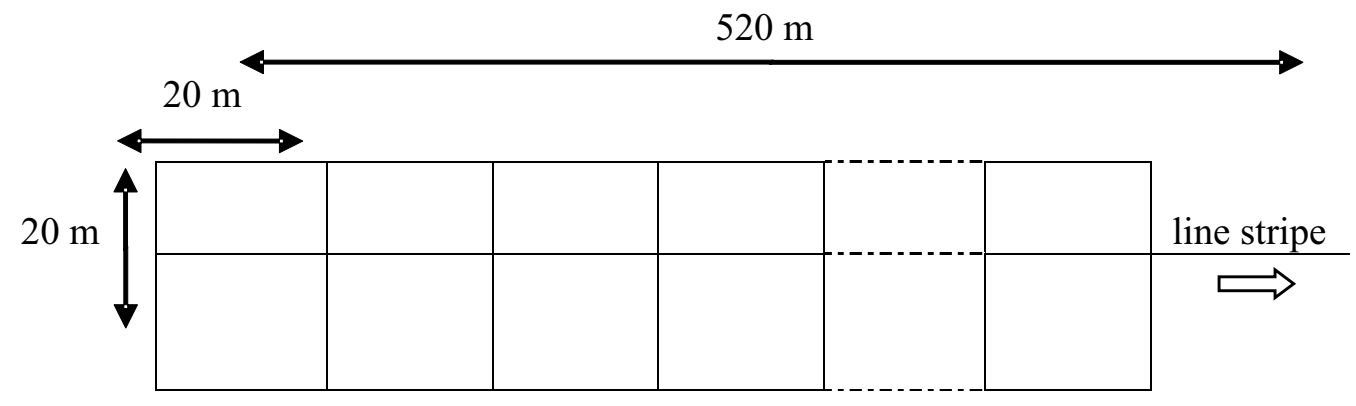

Figure 2 Measurement plot of rattan species observation. 
results, C. zollingeri known as rotan batang (Nupabomba, Donggala District) or rotan air (Maluku). Meanwhile, according to Rustiami (2011), C. zollingeri had local names as rotan batang (Kulawi languange), pondos batang (Minahasa languange), pondos sasiagan (Manado languange), rotan merah (Kolaka languange), or lauro wulemea (Tobela languange).

This species has habitus characteristic of clustering, climbing up to $40 \mathrm{~m}$ long stem with sheath between 50-60 $\mathrm{mm}$ in diameter or stem without sheath between $25-35 \mathrm{~mm}$ in diameter. Leaf sheath woody, dull green, or densely overgrown thorn diverse triangular clay, brown to black tip, short seriate spines, $5-7 \mathrm{~cm}$ long. Knee and orea present. Flagellum absent. Leaves 4-6 m long including cirrus $2 \mathrm{~m}$ and petiole $60-80 \mathrm{~cm}$, broad, deeply channelled above, round beneath and armed with straight, strong spines; rachis rounded beneath, armed along the middle with solitary claws and scattered prickles; leaflets numerous, regulary arranged, lancet and measuring 50-65 $\mathrm{cm} \times 2-3 \mathrm{~cm}$ with 3 veins, gradually acuminate at the tip, plicate at the base, green on both surface, middle vein of under surface armed with long bristles, $3 \mathrm{~cm}$ long; leaf margin smooth, but bristly

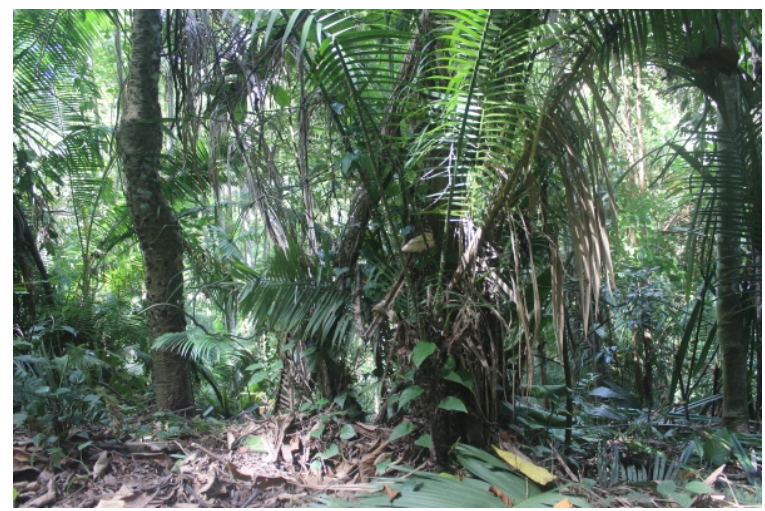

( a )

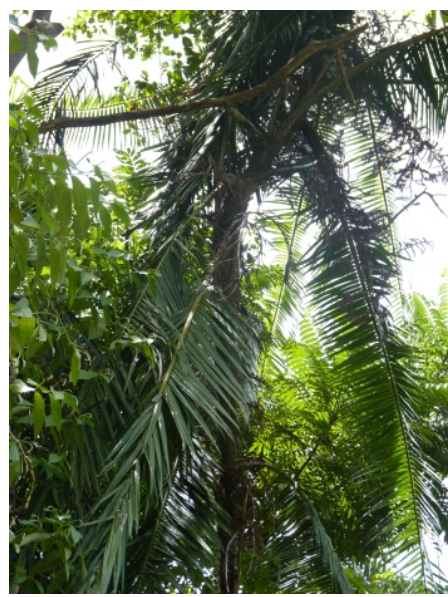

(c) near the tip; amounted 70-85 on each side of rachis. Staminate inflorescence large and many branched and consist of the rachilla. At the time of research no fruit were found (Figure 3 ).

Population of $\boldsymbol{C}$. zollingeri Beccari Observation results of C. zollingeri population at 13 sample plots in Nupabomba forest werevaried. Although the amount of individuals found was relatively large enough (113 clumps in 628 individual stems) but no flowering or fruiting. The species population was dominated byseedling stage (384 stems) (Figure 4a), young rattan (154 stems) (Figure 4b), semi-mature rattan (69 stems) (Figure 4c), and mature rattan (13 stems) (Figure 4d).

The number of individualsfor mature rattan species C.zollingeri (13 stems) stages study area was lower compared to the study on other sites in Dampelas Sojol Subdistrict Donggala Regency (Kunut et al. 2014), the location within Taman Nasional Lore Lindu (LLNP), and outside of LLNP, C. zollingeri (645 individu) (Stiegel et al. 2011) andcompared to the research results in Papalia Protected Forest, Konawe Selatan District, C.zollingeri found more than 40 stems (Uslinawaty et al. 2014). In

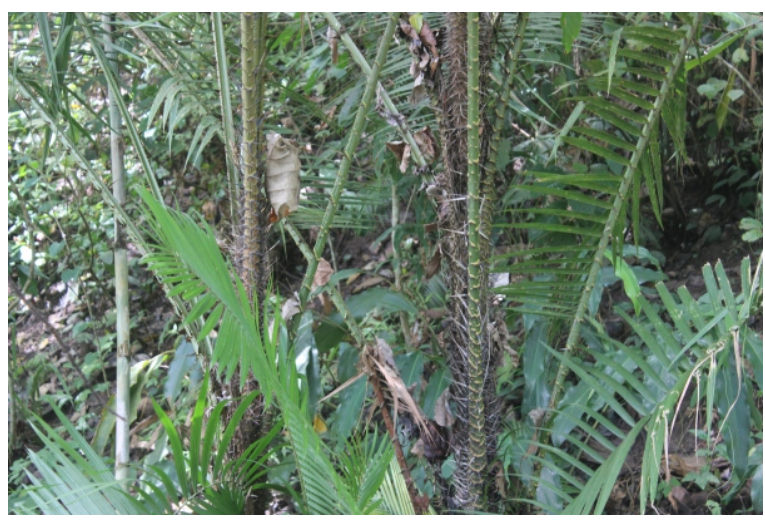

( b )

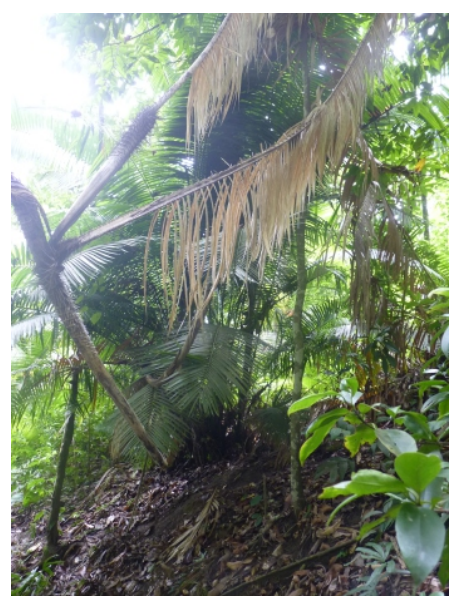

(d)

Figure 3 Calamus zollingeri. a.Seedling stage, b. Young Rattan, c. Semi mature rattan, d. Mature rattan (Photo: T. Kalima) 

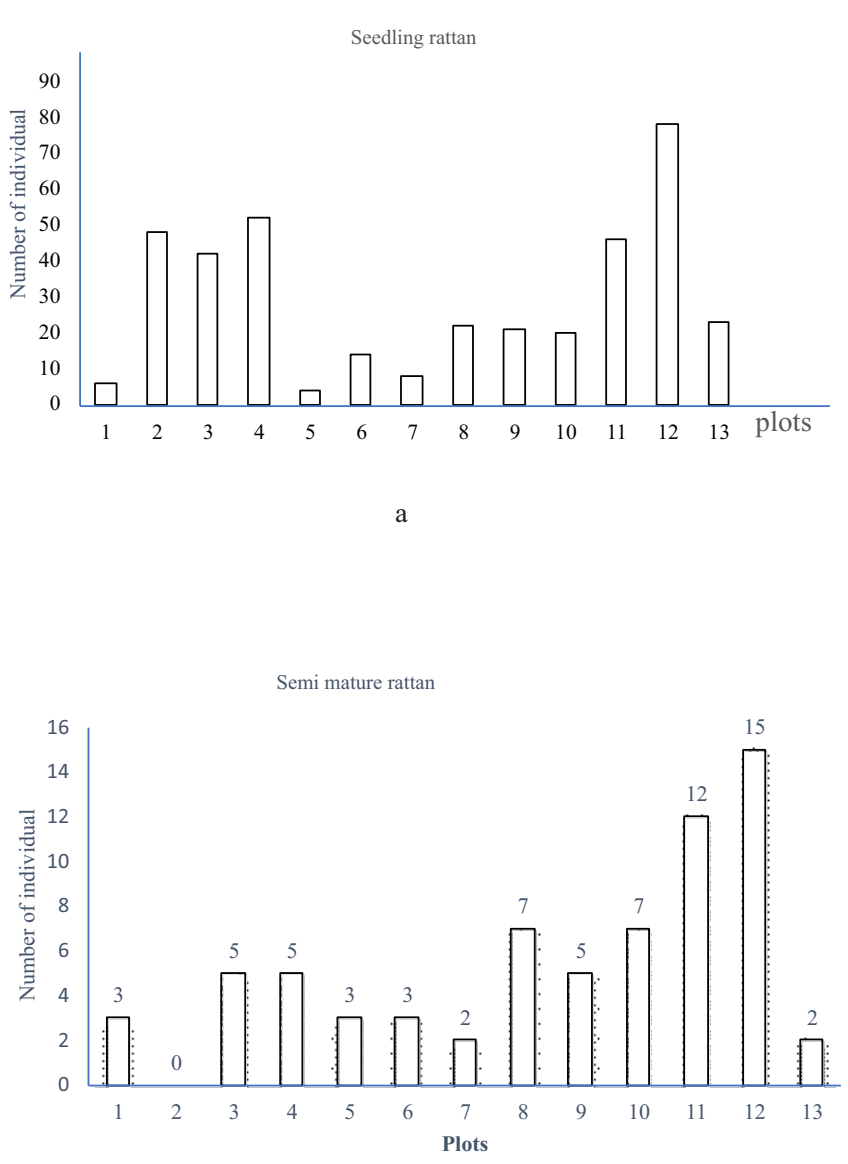

c

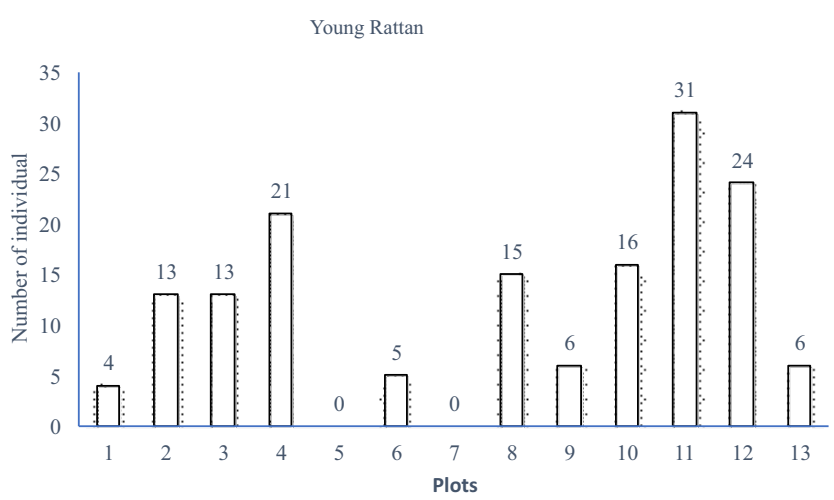

b

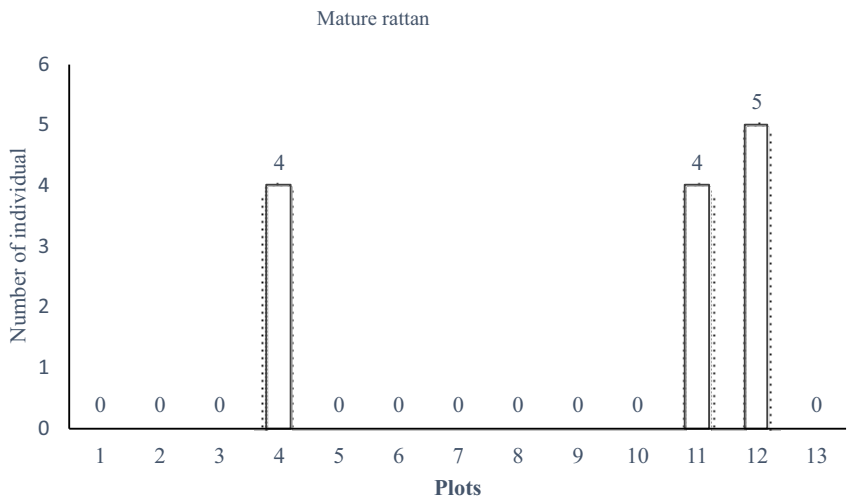

d

Figure 4 The number of individual C.zollingeri species in each observation plot,(4a) seedling stage, (4b) young rattan stage, (4c) semi-mature rattan stage, $(4 \mathrm{~d})$ mature rattan stage

Dampelas Sojol Subdistrict, Donggala Regency, other rattan species was found, namely rotan cacing (C. melanoloma Martius), lambang (C. ornatus), tohiti (C. inops), and noko (C. koordersianus). The low number of $C$. zollingeri stems indicate that the rattan species population is heavily logged. So that this type of rattan is very potential to disappear or extinct if the exploitation is continued. The surrounding communities of the Nupabomba mainly live from agriculture and harvesting of non-timber forest products. The margins of the study area(Nupabomba) are characterized by a mosaic of near-primary forests, secondary forests, forest gardens, and small cacao, coffee, maize, and paddy rice farms (Kessler et al. 2005). The livelihood in Nupabomba Village depends on rattan, coffee, rice, and wood products (Purnomo 2003). Despite designated as KPHP Model Dolago Tanggunung, a lot of forest in Nupabomba is subject to uncontrolled extraction of forest resources, particularly rattan.

These differences might be due to the level of forest degradation. The Dampelas Sojol, LLNP, and Papalia
Protected Forest were relatively less degraded due to less logging and other destructive activities because it was more remote. C. zollingeri is a species that has high economic value and is used as raw material for furniture. But this rattan species is rarely found in Nupabomba forest areas.Because of the increasing international rattan demand, over exploitation is becoming a severe threat to $C$. zollingeri rattan populations (ITTO et al. 2007).

From the distribution histogram (Figure 4) of rattan C.zollingeri, it is seen that each sample plot has a larger number of seedling, young rattan, and semi-mature than mature rattan/old individuals. This distribution illustrated that the regeneration of rattan C.zollingeri is normal (sustainable). The current logging or harvest rates are already exceeding the rattan populations (Siebert 2004). However, Siebert \& Belski (2002) argued that excessive exploitation of rattan could cause serious effects on biodiversity and rich endemic flora and fauna in Indonesia.

Rattan found at each plot reached semi-mature level 
Table 1 The density of Calamus zollingeri Beccari in every plot based on stem length class

\begin{tabular}{|c|c|c|c|c|c|c|c|c|c|c|}
\hline \multirow[t]{2}{*}{ Plot } & \multicolumn{2}{|c|}{ Seedling } & \multicolumn{2}{|c|}{ Young Rattan } & \multicolumn{2}{|c|}{ Semi Mature } & \multicolumn{2}{|c|}{ Mature } & \multicolumn{2}{|c|}{ Total } \\
\hline & $\mathrm{K} \mathrm{ha}^{-1}$ & $\begin{array}{l}\text { KR } \\
(\%)\end{array}$ & $\mathrm{K} \mathrm{ha}^{-1}$ & $\begin{array}{l}\mathrm{KR} \\
(\%)\end{array}$ & $\mathrm{K} \mathrm{ha}^{-1}$ & KR (\%) & $\mathrm{K} \mathrm{ha}^{-1}$ & KR (\%) & $\mathrm{K} \mathrm{ha}^{-1}$ & $\begin{array}{l}\text { KR } \\
(\%)\end{array}$ \\
\hline 1 & 11.54 & 1.56 & 7.69 & 2.60 & 5.77 & 4.35 & - & - & 25.00 & 8.51 \\
\hline 2 & 92.31 & 12.50 & 25.00 & 8.44 & - & & - & - & 117.31 & 20.94 \\
\hline 3 & 80.77 & 10.94 & 25.00 & 8.44 & 9.62 & 7.25 & - & - & 115.38 & 26.63 \\
\hline 4 & 100.00 & 13.54 & 40.38 & 13.64 & 9.62 & 7.25 & 7.69 & 30.77 & 157.69 & 65.19 \\
\hline 5 & 7.69 & 1.04 & - & - & 5.77 & 4.35 & - & - & 13.46 & 5.39 \\
\hline 6 & 26.92 & 3.65 & 9.62 & 3.25 & 5.77 & 4.35 & - & - & 42.31 & 11.24 \\
\hline 7 & 15.38 & 2.08 & - & - & 3.85 & 2.90 & - & - & 19.23 & 4.98 \\
\hline 8 & 42.31 & 5.73 & 28.85 & 9.74 & 13.46 & 10.14 & - & - & 84.62 & 25.61 \\
\hline 9 & 40.38 & 5.47 & 11.54 & 3.90 & 9.62 & 7.25 & - & - & 61.54 & 16.61 \\
\hline 10 & 38.46 & 5.21 & 30.77 & 10.39 & 13.46 & 10.14 & - & - & 82.69 & 25.74 \\
\hline 11 & 88.46 & 11.98 & 59.62 & 20.13 & 23.08 & 17.39 & 7.69 & 30.77 & 178.85 & 80.27 \\
\hline 12 & 150.00 & 20.31 & 46.15 & 15.58 & 28.85 & 21.74 & 9.62 & 38.46 & 234.62 & 96.10 \\
\hline 13 & 44.23 & 5.99 & 11.54 & 3.90 & 3.85 & 2.90 & - & - & 59.62 & 12.78 \\
\hline & 738.46 & 100 & 296.15 & 100 & 132.69 & 100 & 25.00 & 100 & $1,192.31$ & 400.00 \\
\hline
\end{tabular}

Table 2 The density of Calamus zollingeri Beccari natural regeneration of each plotbased on stem diameter class.

\begin{tabular}{|c|c|c|c|c|c|c|c|c|c|c|}
\hline \multirow[t]{2}{*}{ Plot } & \multicolumn{2}{|c|}{ Small diameter } & \multicolumn{2}{|c|}{ Medium diameter } & \multicolumn{2}{|c|}{ Large diameter } & \multicolumn{2}{|c|}{ Super diameter } & \multicolumn{2}{|c|}{ Total } \\
\hline & $\mathrm{K} \mathrm{ha}^{-1}$ & KR $(\%)$ & $\mathrm{K} \mathrm{ha}^{-1}$ & KR (\%) & $\mathrm{K}$ ha $^{-1}$ & KR (\%) & $\mathrm{K} \mathrm{ha}^{-1}$ & KR $(\%)$ & $\mathrm{K} \mathrm{ha}^{-1}$ & KR $(\%)$ \\
\hline 1 & 4.75 & 15.83 & 0.25 & 1.12 & 0 & 0 & 0 & 0 & 5.00 & 16.96 \\
\hline 2 & 4.75 & 15.83 & 0 & 0 & 0 & 0 & 0 & 0 & 4.75 & 15.83 \\
\hline 3 & 4.25 & 14.17 & 4.25 & 19.10 & 0.25 & 2.00 & 0 & 0 & 8.75 & 35.27 \\
\hline 4 & 3.75 & 12.50 & 2.00 & 8.99 & $\begin{array}{l}0.20 \\
5.00\end{array}$ & 2.00 & 0.50 & 28.57 & 6.50 & 52.06 \\
\hline 5 & 2.50 & 8.33 & 0 & 0 & 2.00 & 16.00 & 0 & 0 & 4.50 & 24.33 \\
\hline 6 & 0.75 & 2.50 & 2.00 & 8.99 & 0.25 & 2.00 & 0 & 0 & 3.00 & 13.49 \\
\hline 7 & 0.50 & 1.67 & 0 & 0 & 0.25 & 2.00 & 0 & 0 & 0.75 & 3.67 \\
\hline 8 & 1.25 & 4.17 & 3.75 & 16.85 & 4.75 & 38.00 & 0 & 0 & 9.75 & 59.02 \\
\hline 9 & 4.50 & 15.00 & 6.50 & 29.21 & 2.00 & 16.00 & 0 & 0 & 13.00 & 60.21 \\
\hline 10 & 1.50 & 5.00 & 1.75 & 7.87 & 0.50 & 4.00 & 0 & 0 & 3.75 & 16.87 \\
\hline 11 & 0.50 & 1.67 & 0.25 & 1.12 & 1.75 & 14.00 & 0.50 & 28.57 & 3.00 & 45.36 \\
\hline 12 & 0.50 & 1.67 & 0.75 & 3.37 & 0.25 & 2.00 & 0.75 & 42.86 & 2.25 & 49.89 \\
\hline 13 & 0.50 & 1.67 & 0.75 & 3.37 & 0.25 & 2.00 & 0 & 0 & 1.50 & 7.04 \\
\hline & 30 & 100 & 22.25 & 100 & 12.5 & 100 & 1.75 & 100 & 66.50 & 400.00 \\
\hline
\end{tabular}


Table 3 Species density of tree level that associated with Calamus zollingeri Beccari stem rattan species in Nupabomba producted forest area

\begin{tabular}{lllrr}
\hline \multicolumn{1}{c}{ Local name } & \multicolumn{1}{c}{ Species } & Family & $\mathrm{K} \mathrm{ha}^{-1}$ & KR (\%) \\
\hline Kolokowa & Baccaurea rasemosa (Reinw. ex Blume) Müll.Arg. & Euphorbiaceae & 250.00 & 16.46 \\
Noi & Canarium asperum Benth. & Burseraceae & 76.92 & 5.06 \\
Marambaulu & Celtis philippensis Blanco & Ulmaceae & 173.08 & 11.39 \\
Soi & Dillenia celebica Hoogl. & Dilleniaceae & 19.23 & 1.27 \\
Maraula & Diospyros macrophylla Blume & Ebenaceae & 57.69 & 3.80 \\
Kaili & Dracontomelon dao (Blanco) Merr. \& Rolfe & Anacardiaceae & 115.38 & 7.59 \\
Binuang & Octomeles sumatrana Miq. & Datiscaceae & 38.46 & 2.53 \\
Tambadea & Knema celebica de Wilde & Myristicaceae & 57.69 & 3.80 \\
Lero & Pterospermum celebicum Miq. & Sterculiaceae & 19.23 & 1.27 \\
anloli & Fagraea fragrans Roxb. & Gentianaceae & 153.85 & 10.13 \\
K. Batu & Gironniera subaequalis Planch. & Ulmaceae & 115.38 & 7.59 \\
Ipi & Cryptocarya crassinerviopsis Kosterm. & Lauraceae & 38.46 & 2.53 \\
Tumbawa & Dysoxylum densiflorum (Blume) Miq. & Meliaceae & 76.92 & 5.06 \\
Damar babi & Dacryodes rostrata (Blume) H.J.Lam & Burseraceae & 115.38 & 7.59 \\
Kume & Lithocarpus havilandii (Stapf) Barnett & Fagaceae & 115.38 & 7.59 \\
Koncala & Ardisia celebica Scheff. & Myrsinaceae & 57.69 & 3.80 \\
Renggo & Tarrietia utilis (Sprague) Sprague & Malvaceae & 38.46 & 2.53 \\
\hline & & & 1519.23 & 100
\end{tabular}

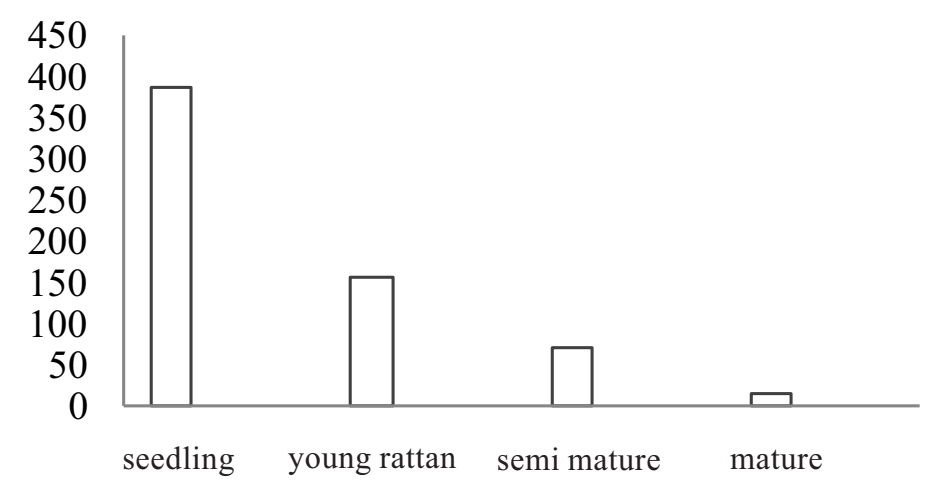

Figure 5 Amount of individual of Calamus zollinger rattan at various growth stages. Amount of individuals ( ).

口

(pole level) with a stem length between 5-15 m (Kalima 2004) and diameter $>18 \mathrm{~mm}$ (BSN 2017). This indicated a high population level of seedlings, young rattan, and semimature rattan which also described a high level of potential growth. Thus it can be explained that rattan species having high-density value was species that having a high potential growth as well. On the contrary, species having a low-density value, their level of potential growth was also low (Table 2).
Natural regeneration Rattan utilization by local community was always available at each village to be traded. So the condition of rattan in Nupabomba forest was a stretch of natural regeneration rattan. According to observation, natural regeneration based on rattan stem length class were abundant, 738.46 stems $^{-1}$ of seedling stage, 296.15 stems $\mathrm{ha}^{-1}$ of young rattan (sapling), 132.69 stems ha $^{-1}$ of semi mature rattan (pole), and 25.00 stems ha $^{-1}$ of mature rattan 
(adult cane) (Table 1). Species density was determined by growth site factor, competition, and relationship with other species (Wahyudi \& Janneta 2011). It seems that the surrounding ambient temperature has affected the density, so that the seedling, young rattan, and semi-mature that were found in the study sites can flourish in moist areas due to their position that was nearby the river banks. The growth of rattan is supported by its peripheral trees. According to Martono (2010), the potential climbing trees are generally strong, have low branches, and grow fast. From observation results, it was showed that host trees for rattan climbing grew in variation, which commonly used for rattan that abundant at study site are Baccaurea rasemosa, Celtisphilippensis, Dracontomelon dao, Fagraea fragrans, and other tree species. In general, rattan species will climb at host trees having the less heavy crown and tended to seek thin crown trees where sunlight was still able to penetrate crown gap below the trees. It was suspected that rattan species seek sunlight.

Growth composition of 628 individualstems showed that amount of seedlings were much higher than individual adult rattan (mature rattan) (Figure 5). This meant that in the study site, natural regeneration potential of this $C$. zollingeri species was relatively abundant. However, abundant seedlings also ensure sustainability of $C$. zollingeri in the future if illegal logging and forest encroachment were stopped, so thatamount of trees for rattan to climb are sufficient. C. zollinger needs climbing tree for their live.

Figure 5 above showed that the tendency of C.zollingeri followed reverse J-shaped distribution from small individuals with a diameter below $50 \mathrm{~mm}$. Rattan stand structure with reverse J curve was generally found in tropical rain forests which describe a dynamic of forest communities (Hidayat 2014). While for mature rattan, its presence percentage was larger and tended to decrease drastically as figured in histograms. When compared cutting of mature rattan in 1996 (37 stems) and in 2000 (3 stems) (Siebert 2000), there were more (13 stems) in this research. Such conditions commonly occur in tropical rainforests, which confirmed that the condition of the forests was still normal (Dendang \& Hand 2015). Thus, in the research site, a natural regeneration occurred due to mature rattan cane harvesting was continuously carried out, so seedling growth rate would replace the growth rate of the adult rattans (mature rattan).

Result of observation distribution of batang rattan $(C$. zollingeri) diameter class in the research site, the highest entire plot density occurred at small-diameter class (5-18 mm) (BSN 2017). Rattan density was drastically reduced with increasing stem diameter class, even some individuals rattans were absent in certain class diameter. Super diameter rattan was found only in plots 4,11 and 12 . It was in a very low density of $0.50 \mathrm{stem} \mathrm{ha}^{-1} ; 0.50 \mathrm{stem} \mathrm{ha}^{-1}$, and 0.75 stem ha ${ }^{1}$, respectively. The number of individuals of C.zollingeri in logged forests differed from unlogged forests (Table 2).

Association with vegetation As a whole, as many as 17 tree vegetation species were encountered that grow in association withC. zollingeri species. Detailed results of tree vegetation analysis in 13 observations plot were presented in Table 3.

It could be seen in Table 3 that the large species associated with C. zollingeri was kolokowa species
(Baccaurea rasemosa (16.46\%), marambaulu (11.39\%), and anloli $(10.13 \%)$. While the rare species found was soi (Dillenia serrata), bayur, ipi, renggo, and maraula. According to Kessler et al. (2002), Pterospermum celebicum and Dillenia celebica species are protected and endemictree species in Sulawesi based on SK Mentan Numbered 54/Kpts/Um/2/1972 and Government Regulation (Peraturan Pemerintah) No. 7 Tahun 1999). Mogea (2004) reported that Knema celebica was one of the rare and endanger species that threaten to extinction in Sulawesi. In the tropical rainforest, many trees grow in the same area resulting in competition to survive and grow normally. Hence, the density of trees can affect growth and even mortality of trees (Murdjoko et al. 2016). The presence of other trees can also be a factor that affects rattans' growth (Ruslandi et al. 2012). Even though fauna also plays important role in tree survival, the contribution of fauna will not be taken into account during this study (Murdjoko et al. 2016).

Utilization management The high intensity of forest utilization pressure, either legal or illegal had resulted damage and eliminating species diversity especially the existence of rattan species in nature. It is one of the reasons why there was no involvement of communities around the forest in managing forest areas. Community, in this case, had an important influence in the utilization and conservation of the existence of batang rattan (C). zollingeri). The fact in the research location, they were collecting semi-mature and mature rattan canes- It was known from the existence of young rattan clump and seedlings which were left abundant. The existence of young rattan and seedling regeneration were a guarantee the sustainability of $C$. zollingeri population growth in the future.

It was necessary to make a conservation approach in forest ecosystem management with collaborative efforts with communities living around the forest to overcome many complex problems in the management of rattans. Results of interviews with forest communities with the aim of improving the productivity of non-timber forest products (NTFPs) especially rattan were obtained. The forestre mained sustainable and run its main function wellso that it can be beneficial to the welfare of surrounding communities.

Based on C. zollingeri regeneration population existed in forest area, then ideally species selection to be cultivated were other commercial rattan. These commercial rattans were an in-situ plant that grow on their habitats (local priority rattan species) and ecologically they also fulfilled site suitability conformity at the local area.

Conservation efforts $C$. zollingeri is widely used in general because it has a flexible, strong, and relatively uniform shape (Gautama 2008). Therefore, protecting the existence of this rattan species is urgently necessary. Sustaining an $C$. zollingeri in its natural habitat was the best practice. Thus, efforts to conserve rattans finally became hugeneeds in community level. In such cases, ex-situ conservation must be applied, so that the maximum amount of genetic variation of available species that can still be saved and gave chances to survive. Therefore, forests and rattan as one of the species of flora in it, need to be developed to improve the preservation, 
utilization, and conservation of its genetic resources (Hong et al. 2001). In addition, knowledge of the genetic diversity within rattan species is still scarce. With the fast depletion of the tropical forests, it is imperative to obtain this knowledge for the sustainable management of the remaining rattan resources.

One of the efforts that was done in 2016 was the planting of the local priority rattan species in 5 ha area of Nupabomba forest (Prameswari \& Kalima 2018). That rattan species is Daemonorops robusta which is commercial rattan species (Kalima \& Jasni 2015). Thus, it is expected that farmers or rattan collectors in that rattanproducing areas can benefit from natural resource production.

\section{Conclusions}

The natural regeneration of $C$. zollingeriin the study site showed that the condition of harvested forest was still relatively good. Distribution of individual seedling of $C$. zollingeri tended to increase after logging due to environmental factors. Local community is very dependent on the rattan existence to fulfill their daily livelihood and in addition also as a cash income source. Such utilization, however, is mostly conducted in an unsustainable way, for instance, by cutting rattan unselectively or cutting trees that cause rattan cluster to die. The successful of the local community in sustainably managing rattans resources will, indeed, help local government in rural development throughout Central Sulawesi. The cultivation of some other local priority rattans species should be developed to fulfill local people requirements of forest products mainly rattan. It could be developed in customary forests or community forests. The existing customary forest and community forests must be supported in terms of management and marketing. This development could be one of the efforts to reduce forest degradation.

\section{Recomendation}

Further studies of relationships between the natural regeneration of $C$. zollingeri species and site-specific environmental conditions are also warranted. Central Sulawesi is ideally suited for this work due to its abundant and diverse rattan flora, complex geology, extreme elevation gradients, and varied climatic conditions.

\section{Acknowledgment}

We would like to convey our sincerely gratitude to Director of Forest Research and Development Centre, Dr. Ir. Kisfianti Linda Ginoga, M.Sc., for her advice, attention, and valuable discussion during implementation of this research. We are also very much in debt to manager and staff of Production Forest Management Unit (KPHP) Dolago Tanggunung and people from Nupabomba, Tanantovea Subdistrict, Donggala District, Central Sulawesi for helping us in various ways. We would like to thank all technicians of Herbarium Botany and Forest Ecology, FRDC Bogor for helping us in species identification. Finally, we thank Drs. Riskan Effendi, Msc in sharing support and good companion during finishing this research article. Undeniably that without their presence beside us, it is impossible for us to complete this research.

\section{References}

Arifin YF. 2008. An inventory of types and habitat of rattan in the forest of the highland and the lowland of Borneo South, Faculty of Forestry, Lambung Mangkurat University, Banjarbaru, South Kalimantan. Biota 13(3):141-146.

[BPS] Badan Pusat Statistik. 2011. Kabupaten Donggala Dalam Angka. Kerjasama Badan Perencanaan Pembangunan Daerah dan Penanaman Modal Kabupaten Donggala. Donggala: Badan Pusat Statistik Kabupaten Donggala.

[BSN] Badan Standar Nasional. 2017. Jenis, Sifat, Kegunaan dan Persebaran Rotan. SNI 7208-2017.

Curran L, Trigg S, Mc Donald A, Astiani D, Hariono Y, Siregar P, Caniago I, Kasischke E. 2004. Lowland forest loss in protected areas of Indonesia Borneo. Science 303:10001003. https://doi.org/10.1126/science.1091714

Dendang B, Handayani W. 2015. Struktur dan komposisi tegakan hutan di Taman Nasional Gunung Gede Pangrango, Jawa Barat. Prosiding Seminar Nasional Masyarakat Biodiversitas Indonesia 1:691-695. https://doi.org/10.13057/psnmbi/m010401.

[FAO] Food and Agriculture Organization. 2011. Indonesia: Call to revamp trade and export of rattan. Etherington T., Muir G., Mitchell R.. Lazarev A., \& Fanego D, editors. 7 Non-wood News Vol. 22.

Gautama I. 2008. Analisis biaya dan proses pemanenan rotan alam di Desa Mambue Kab Luwu Utara. Jurnal Hutan dan Masyarakat 3(1):1-110.

Groombridge B, Jenkins M. 2002. World Atlas of Biodiversity. California: University of California Press Berkeley.

Hidayat S. 2014. Kondisi vegetasi hutan lindung Sesaot, Kabupaten Lombok Barat, Nusa Tenggara Barat, sebagai informasi dasar pengelolaan kawasan. Jurnal Penelitian Kehutanan Wallacaea 3(2):97-105. https://doi.org/10. 18330/jwallacea. 2014.vol3iss2pp97-105.

Hong LT, Rao VR, Amaral W. 2001. Research on rattan genetic resources conservation anduse: The perspective and strategy of the International Plant Genetic Resources Institute Unasylva. Pp.52-56.

[ITTO] The International Timber Organization, Ministry of Forestry Republic of Indonesia 2007. Inventory of standing stocks in natural forest and plantation; Development of sustainable rattan production and utilization through participation of rattan smallholders and industry in Indonesia: 29p. 
Jasni K, Kalima T, Malik J, Abdurachman. 2012. Atlas Rotan Indonesia. Jilid 3. Bogor: Pusat Penelitian dan Pengembangan Keteknikan Kehutanan dan Pengolahan Hasil Hutan.

Kalima T, Jasni. 2015. Prioritas penelitian dan pengembangan jenis rotan andalan setempat. Di dalam: Prodising Seminar Nasional Masyarakat Biodiversitas Indonesia 1; Solo, tanggal (8). Pp. 1868-1876.

Kalima T. 2004. Permudaan alami spesies rotan di Kawasan Taman Nasional Gunung Halimun, Jawa Barat. Jurnal Penelitian Hutan dan Konservasi Alam 1(3):356-365.

[KPHP] Kawasan Pengelolaan Hutan Produksi. 2013. Buku Rencana Pengelolaan Hutan Jangka Panjang KPHP Model Dolago Tanggunung di Kabupaten Parigi Moutong, Kabupaten Sigi, Kabupaten Donggala dan Kota Palu Provinsi Sulawesi Tengah. Palu: Balai Pemantapan Kawasan Hutan Wilayah XVI Palu.

Keßler PJA, Bos MM, Sierra Daza SEC, Kop A, Willemse LPM, Pitopang R, Gradstein SR. 2002. Checklist of woody plants of Sulawesi, Indonesia. Blumea Suplement 14(1):11-60.

Kessler M, Keßler PJA, Gradstein SR, Bach K, Schmull M, Pitopang R. 2005. Tree diversity in primary forest and different land use systems in Central Sulawesi, Indonesia. Biodiversity \& Conservation 14(3):547-560. https://doi.org/10.1007/s10531-004-3914-7.

Kidyoo AM, McKey D. 2012. Flowering phenology and mimicry of the rattan Calamus castaneus (Arecaceae) in southern Thailand. Botany 90(9):856-865. https://doi.org/10.1139/b2012-058.

Kunut AA, Sudhartono A, Toknok B. 2014. Keanekaragaman jenis rotan (Calamus spp.) di kawasan hutan lindung wilayah Kecamatan Dampelas Sojol, Kabupaten Donggala. Warta Rimba 2(2):102-108.

Martono D. 2010. Rattan cultivation technique, research and development of forest produce in Bogor (in Indonesian). Paper presented at Workshop on Facilitating Enterprise Development of Forest Produce Other than Wood (HHBK), Palangka Raya, August 24, 2010.

Murdjoko A, Marsono D, Sadono R, Hadisusanto S. 2016. Tree association with Pometia its structure in logging concession of South Papua Forest. Jurnal Managemen Hutan Tropika 22(3):180-191. https://doi.org/ 10.7226/jtfm.22.3.180.

Mogea JP. 2004. Preliminary study on the palm flora of the Lore Lindu National Park, Central Sulawesi, Indonesia. Biotropia 18:120.

Prameswari D, Kalima T. 2018. Reintroduksi jenis spesies Daemonorops robusta Warb. Ex Beccari di Hutan Produksi Dolago Tanggunung, Nupabomba, Sulawesi Tengah. Di dalam: Prosiding Seminar Nasional
Silvikultur V dan Kongres Masyarakat Silvikultur Indonesia IV; Kota, tanggal. Pp 315-325.

Purnomo H. 2003. A system dynamic model for developing policy options of sustanaible and equitable forest management. Jurnal Manajemen Hutan Tropika $9(2): 45-62$.

Ruslandi, Halperin J, Putz FE. 2012. Effects of felling gap proximity on residual tree mortality and growth in a dipterocarp forest in East Kalimantan, Indonesia. Journal of Tropical Forest Science 24(241):110-124.

Rustiami H. 2011. Revision of Calamus and Daemonorops (Arecaceae) in Sulawesi [thesis]. Bogor: Bogor Agricultural University.

Senoaji G. 2010. Studi kesesuaian lahan untuk penentuan kawasan lindung Konak Kabupaten Kepahiang Propinsi Bengkulu. Jurnal Ilmu Kehutanan 4(1):12-20.

Shaanker RU, Ganeshaiah KN, Srinivasan K, Ramanatha RV, Hong LT. 2004. Bamboos and Rattans of The Western Ghats-population Biology, Socio-economics and Conservation Strategies. Bangalore: Ashoka Trust for Research in Ecology and the Environment (ATREE) .

Siebert SF. 2000. Sustainable harvesting of wild rattan: Viable concept or ecological oxymoron?. Retrieved from http://www.fao.org/docrep/003/x9923e/x9923e12.htm\# TopOfPage.

Siebert SF, Belsky JM. 2002. Livelihood security and protected area management. International Journal of Wilderness 8:38-42.

Siebert SF. 2004. Demographic effects of rattan cane collecting and implications for sustainable harvesting. Conservacy Biology 18:424-431.

Siebert SF. 2005. The abundance and distribution of rattan over an elevation gradient in Sulawesi, Indonesia. Forest Ecology and Management 210:143-158. https://doi.org/ 10.1016/j.foreco.2005.02.015.

Soerianegara I, Indrawan A. 2005. Ekologi hutan Indonesia. Bogor: Fakultas Kehutanan, Institut Pertanian Bogor.

Stiegel S, Kessler M, Getto D, Thonhofer J, Siebert SF. 2011. Elevational patterns of species richness and density of rattan palms (Arecaceae: Calamoideae) in Central Sulawesi, Indonesia. Biodivers Conservacy 20:1987-2005. https://doi.org/10.1007/s10531-0110070-8.

Sunderland TCH, Dransfield J. 2002. Species profiles of rattans. In: Rattan: Current .Issues and Prospects for Conservation and Sustainable Development (Dransfield J, Tesoro FO, \& Manokaran N, editors). Rome: FAO.

Uslinawaty Z, Rosmarlinasiah, Asrun. 2014. Morphology and level of abundance of Rattan Papalia protected forest district in South Konawe. Biowallacea 1(2):90-96. 
Wahyudi A, Jannetta S. 2011. Potensi dan permudaan alam rotan penghasil jernang di kawasan Taman Nasional
Bukit Tigapuluh, Riau. Jurnal Penelitian Hutan dan Konservasi Alam 8(3):237-243. https://doi.org/ 10.20886/jphka.2011.8.3.237-243 